\title{
Thrust Measurement of Different Rocket Engines
}

\author{
Mohd Harridon ${ }^{1,2}$, Haslinawati Besar Sa'aid ${ }^{1}$, Hazariah Mohd Noh¹, Puteri Nur Syaza Wardiah ${ }^{1}$, Muhamad \\ Nurazmi Abas ${ }^{3}$, Mohd Abdul Karim ${ }^{3}$, Muhammad Zikry Hilmi ${ }^{3}$, Mohammad Azlan Amran ${ }^{3}$ \\ ${ }^{1}$ Space Tech Center Universiti Kuala Lumpur Malaysian Institute of Aviation Technology, \\ ${ }^{2}$ Malaysia Civil Defence Force, \\ ${ }^{3}$ Space Technology Division Serba Dinamik \\ DOI: 10.29322/IJSRP.11.01.2021.p10973 \\ http://dx.doi.org/10.29322/IJSRP.11.01.2021.p10973
}

\begin{abstract}
Several miniature rocket motors or engines were tested where a probe that measured the thrust of the engines was used to gain meaningful thrust data from 4 types of engines. The engines were positioned horizontally in a contraption to allow measurements to be taken. The breadth of variations from the designated thrusts indicated from the manufacturer were recorded, discussed, and concluded.
\end{abstract}

Index Terms- Rocket, Thrusts Measurement, Rocket Engine Performance

\section{INTRODUCTION}

$\mathrm{T}$ he Space Age consists of several components and one of the components is rocket. Rockets are used to carry payloads and examples of payloads are satellites, humans, spacecraft, and others. There are several variations of rockets with different types of propellants depending upon the missions. Varnier had stated that there were several types of rockets with different thrusts produced and different magnitude of thrusts would produce different volume of noises [1]. He indicated it is vital to measure the thrust produced in order to verify the performances of such rockets [1].

As stated earlier, rockets were used to send satellites into orbits. One such satellite is the satellite that is utilized for Search and Rescue Operations. Harridon stipulated that in Search and Rescue Operations it's imperative for the best and up to date technology be used in order to gain a meaningful and optimum Search and Rescue process [2]. The satellite Cospas-Sarsat is a great tool and equipment that aided Search and Rescue Operations and was transported to space by designated rockets.

This paper lays out the measurements of thrust of rocket engines and the measurements were based upon the equation below.

$\mathrm{T}=\mathrm{m} \mathrm{V}_{\mathrm{e}}+\left(\mathrm{p}_{\mathrm{e}}-\mathrm{p}_{\mathrm{a}}\right) \mathrm{A}_{\mathrm{e}}$

In the equation above, $\mathrm{m}=$ flow rate, $\mathrm{V}_{\mathrm{e}}=$ exhaust velocity at nozzle exit, $p_{e}=$ exhaust pressure at nozzle exit, $p_{a}=$ ambient pressure, and $A_{e}=$ nozzle exit area. The equation took into account several parameters and our rocket engines had different values of parameters and thus measurements of the engines showed different values of thrusts which conform with the equation shown.
The rocket engines that the author had tested were manufactured by a company which had numerous experiences in fabricating rocket engines. According to Bitter, testing a model is crucial as it would offer insights upon the design and performance of the model before real flights were performed [3]. Bitter had tested a model rocket where sub and supersonic flows were analyzed [3]. The author's approach was similar but within the context of thrust of rocket engines.

Babuk had also measured the thrust or rather the combustion of rocket engines but his approach is more towards the mathematical calculation of the combustion [4]. This shows that it is important to gain valuable information regarding the thrusts of the rockets as these showed the performances of the rockets.

\section{LITERATURE REVIEW}

The author measured the thrust of the rocket engines by rigidly connecting the engines to beams and a strain gauge was etched upon one of the beams to gain the force produced by the engines. The thrust measurement system is almost similar to the one employed by Desrochers [5]. Desrochers indicated that the deflection of the beams gave indication of the thrust of the rocket engines [5]. The author followed suit with this approach.

Penn also measured the thrusts of rocket engines by using Vernier's Lab Pro and a force transducer [6]. Penn had managed to obtain meaningful data that showed an almost similar apparition to the data from the rocket engine manufacturer [6].

As mentioned before, thrust measurement would give us an indication of the performance of the rocket and this is important as payloads are needed to be slotted at the correct position and this dependable upon the integrity of the rocket. Satellites play an important role and Pappu stated that the data or images from satellite were used to map the archaeological sites and subsequently unearthed them [7]. Pappu's research had focused upon the usage of satellites for historical purposes [7].

Another functionality of rocket is to deploy tracking satellites where these satellites could track aircraft movement. This is vital for crash investigation and Harridon had actuated crash analyses of helicopter Guimbal Cabri G2 where the usage of new technology could aid air crash investigations [8].

Another research of Harridon dealt with the usage of satellites for optimization of Search and Rescue and Harridon 
stated that the advent of technology had improved Search and Rescue and this showed the importance of testing the rockets in order for them to successfully deploy the needed satellites [9].

Several model rocket engine exists where a majority uses propellant of solid in nature. Campbell had dissected a model rocket engine and using a spectroscopy he concluded that the propellant was black powder which consisted of components of nitrate, sulfur, and carbon [10]. Campbell had also measured the thrust of the rocket engine where piezoelectric crystal was applied to gain the values of thrusts [10].

Another application of rocket is to launch satellites that offers Global Positioning System (GPS) data to individuals. These individuals could use GPS data to track their cumulative distance covered. According to Harridon, academicians at an aviation institute had been ingrained with physical strains and several methodology of physical exercises were laid out to decrease these strains and these academicians would benefit in the utilization of the GPS where they could analyze the physical walk they had covered and mitigate a plan to gain certain physical goal [11].

Navarrete-Martin had analyzed the solid propellant of rocket engines and had simulated the burn characteristics of the propellant in order to gain an understanding of the performance of the rocket engine [12]. She indicated that the results from the simulation had aided the rocket to reach additional altitude and furthermore increase the performance of the rocket.

\section{METHODOLOGY}

The steps or methods to measure the thrusts of the rocket engines are shown in Figure 1.

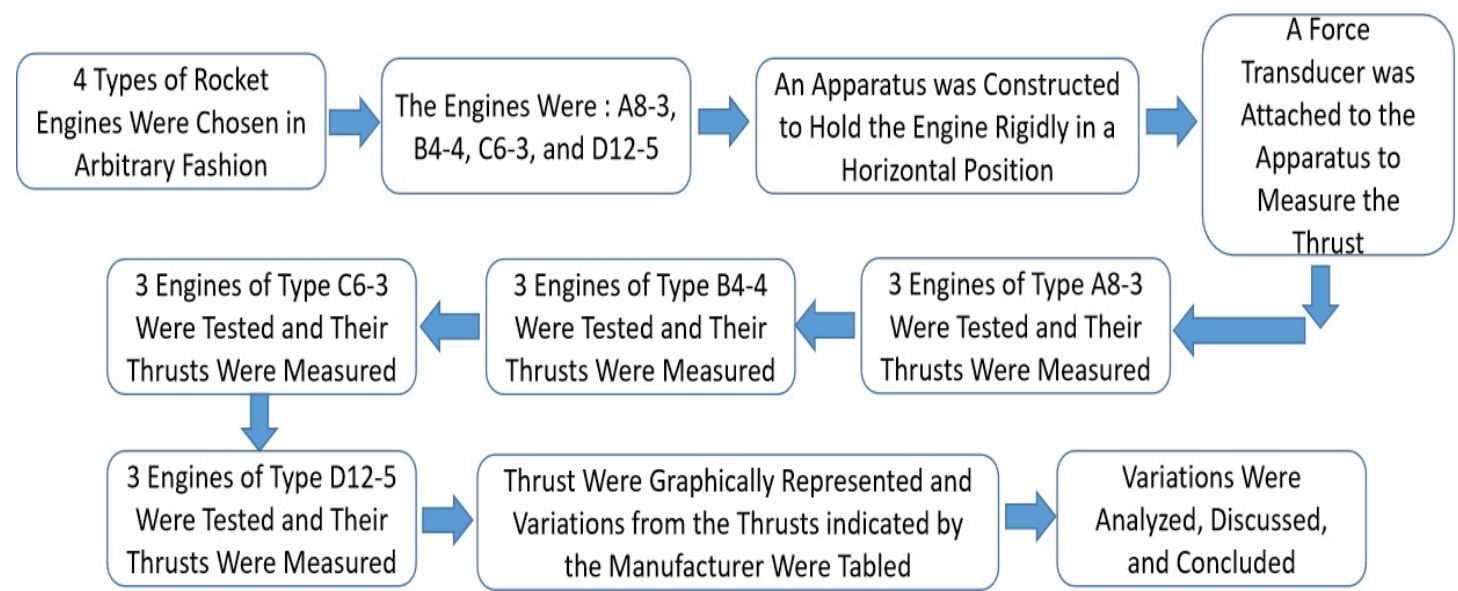

Figure 1. The Methodology to Obtain the Thrusts and Variations of the Rocket Engines

The author had arbitrary chosen 4 types of rocket engines that were fabricated by a well established organization that had in depth experiences in building miniature rocket engines. The chosen engines were A8-3, B4-4, C6-3, and D12-5. The author then constructed an apparatus that had hold the rocket engines rigidly and the engines were fired in a horizontal position. A force transducer which is a strain gauge had been etched onto the beam of the apparatus and the deflection of the beam had given voltage readings which were converted into data of thrusts.

3 engines of A8-3 were tested and measurement of thrusts were recorded. Similarly 3 engines of B4-4 were tested and their thrusts were recorded. Engine of type C6-3 were also tested where 3 of them were fired and their thrusts were recorded. 3 engines of type D12-5 were also fired horizontally and data of their thrusts were recorded. The data of the thrusts were graphically represented and a table was also produced that showed the variations of the measured thrusts in tandem with the thrusts specified by the manufacturer. These variations were analyzed, discussed, and conclusions were made.

\section{RESULTS}

The measurements of maximum thrusts of different rocket engines are shown in Figures 2, 3, 4, and 5. Table 1 indicates the variation of maximum thrusts of different rocket engines in relation to the maximum thrusts indicated by the manufacturer. 

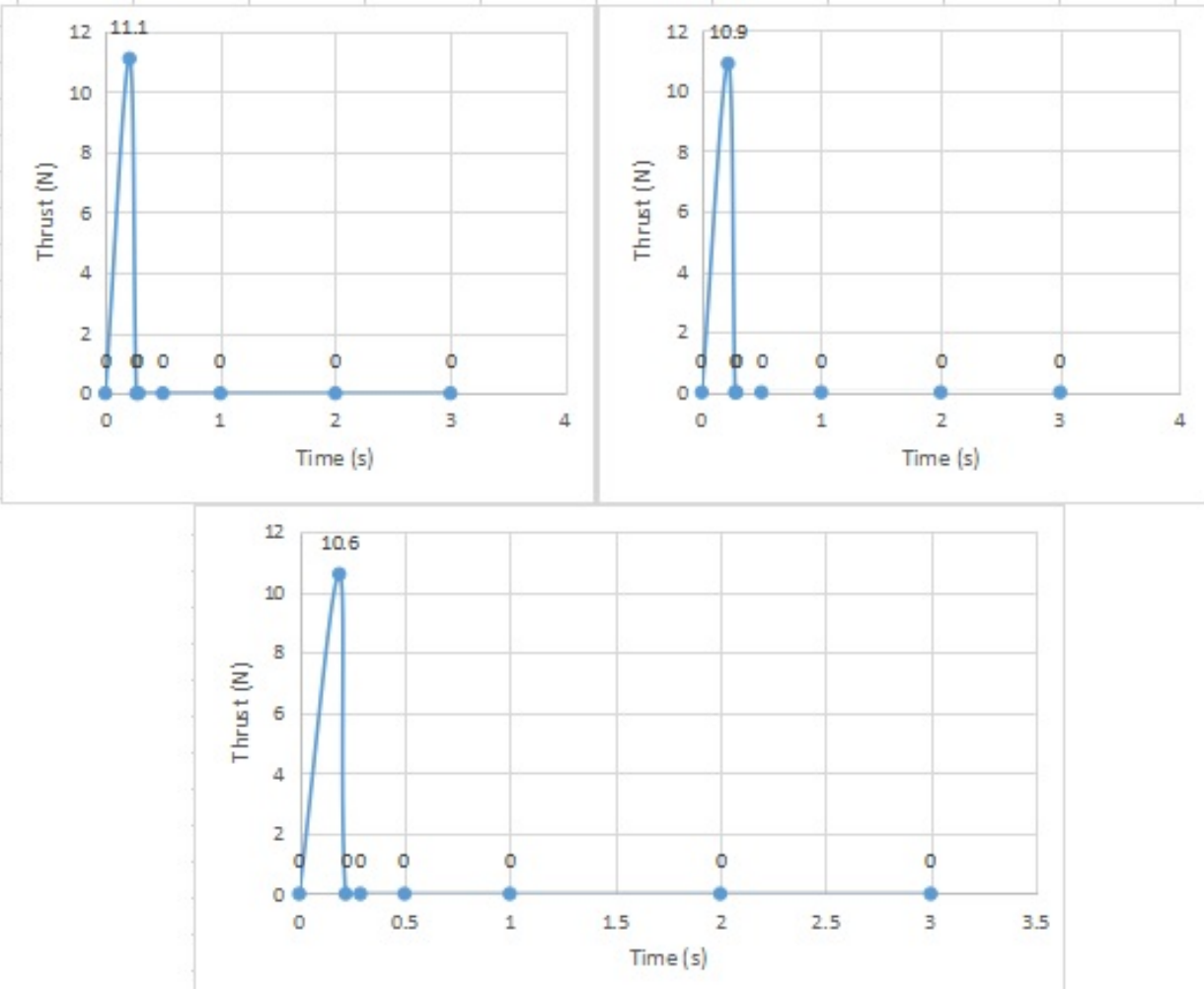

Figure 2. Maximum Thrust of Rocket Engine A8-3
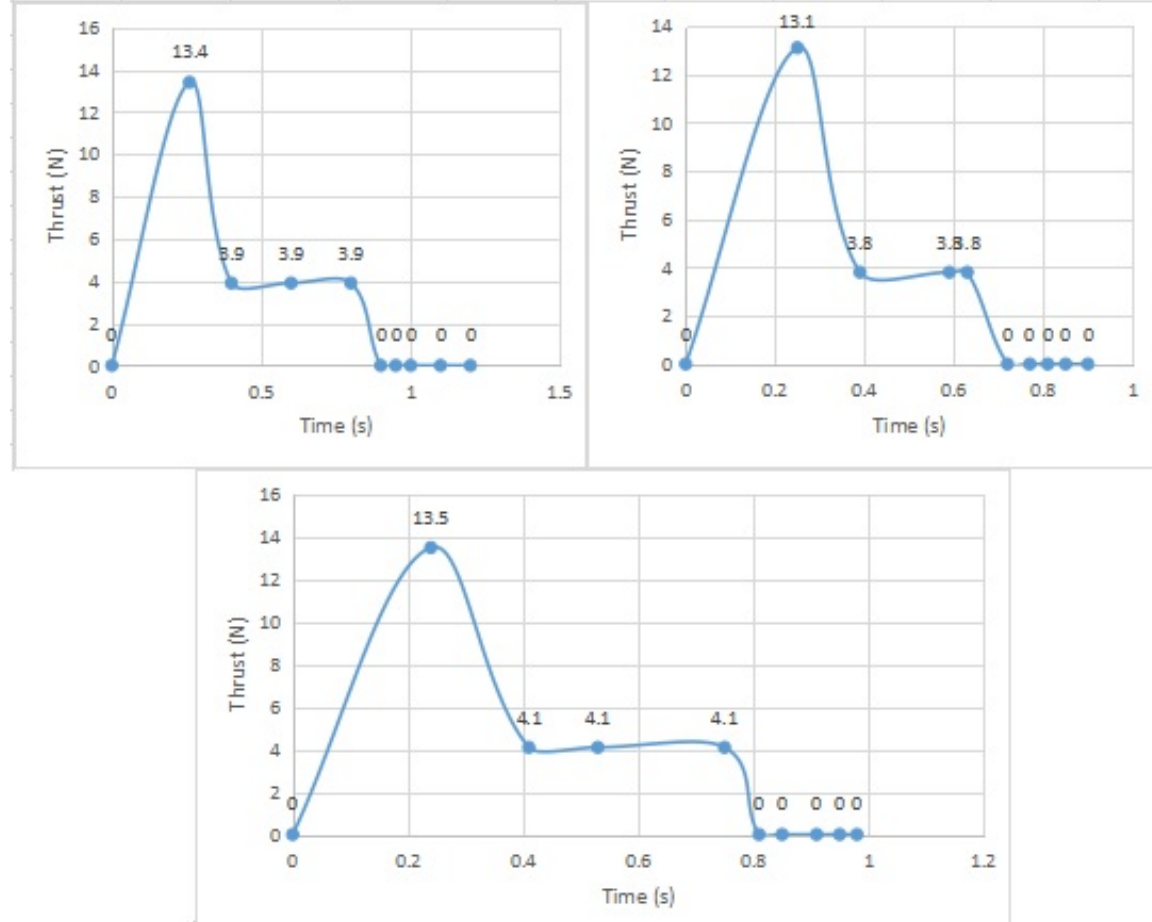

Figure 3. Maximum Thrust of Rocket Engine B4-4 

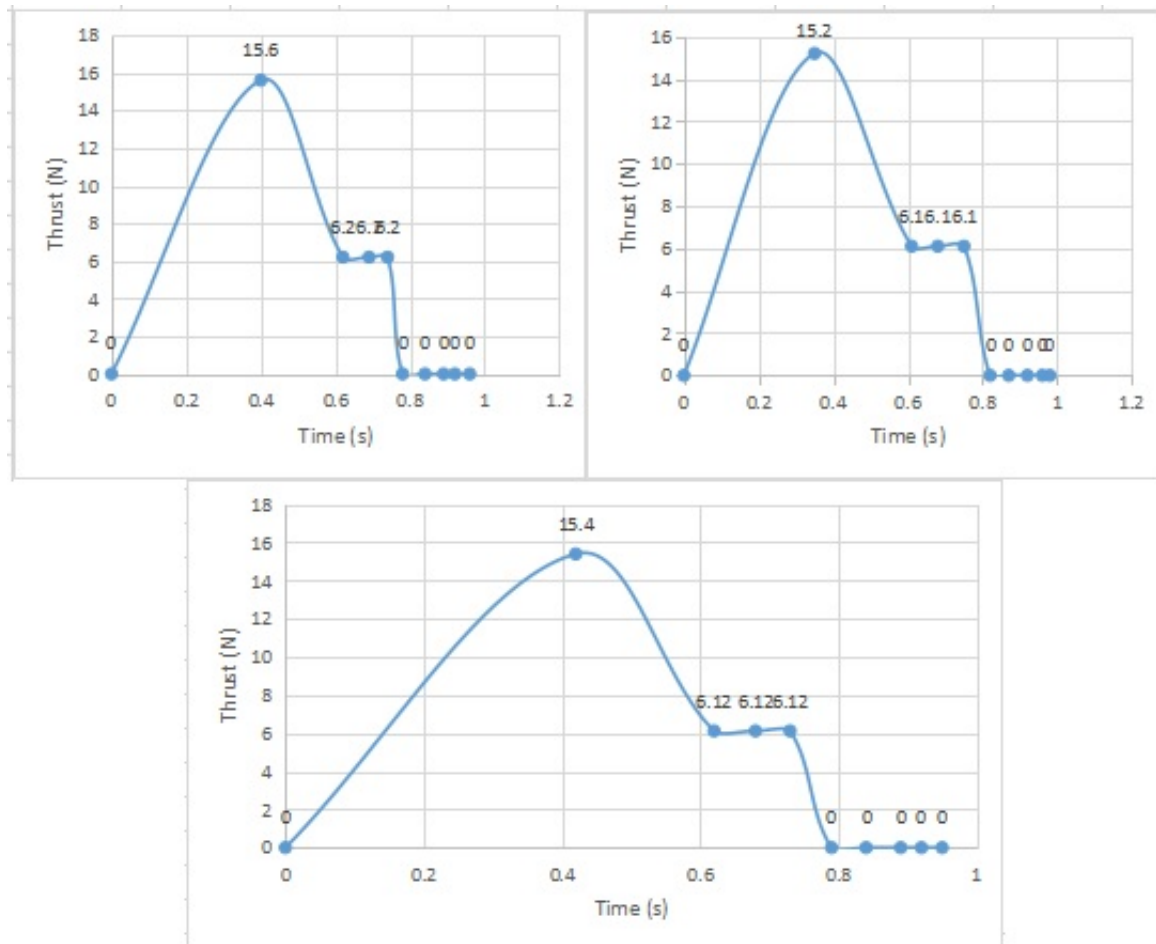

Figure 4. Maximum Thrust of Rocket Engine C6-3
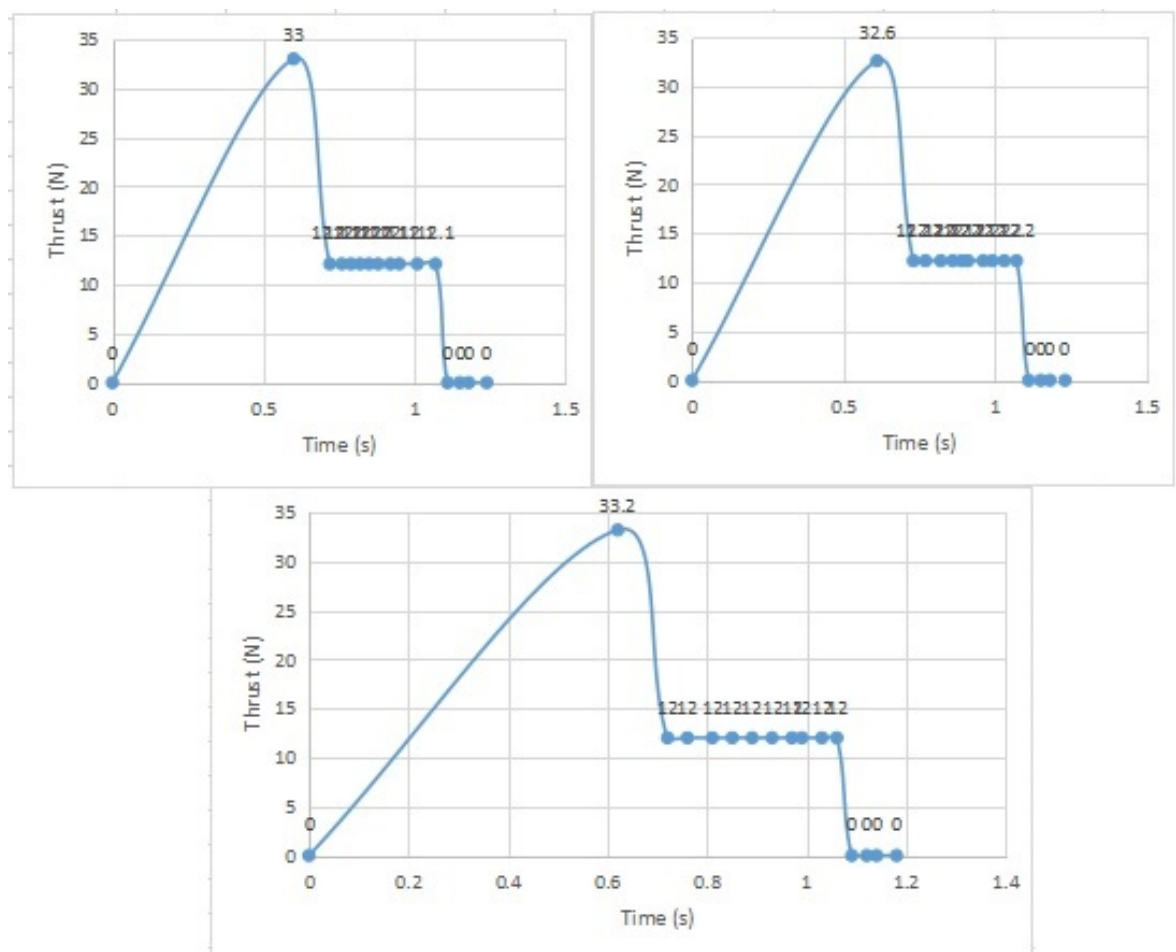

Figure 5. Maximum Thrust of Rocket Engine D12-5 
Table 1. Variation of Measured Maximum Thrust

\begin{tabular}{|c|c|c|c|c|c|c|}
\hline No & $\begin{array}{l}\text { Rocket } \\
\text { Engine }\end{array}$ & $\begin{array}{lr}\text { Max } & \text { Thrust } \\
\text { Stated } & \text { by } \\
\text { Manufacturer } \\
(\mathrm{N}) & \\
\end{array}$ & $\begin{array}{l}\text { Max Thrust } \\
\text { Via } \\
\text { Measurement } \\
\text { (N) } \\
\end{array}$ & $\begin{array}{l}\text { Variation } \\
\text { (N) }\end{array}$ & $\begin{array}{l}\text { Variation } \\
(\%)\end{array}$ & $\begin{array}{l}\text { Average Max } \\
\text { Thrust Via } \\
\text { Measurement } \\
\text { (N) }\end{array}$ \\
\hline 1 & $\begin{array}{l}\text { A8-3 (First } \\
\text { Engine) }\end{array}$ & 10.7 & 11.1 & 0.4 & 3.738 & \multirow{3}{*}{10.867} \\
\hline 2 & $\begin{array}{l}\text { A8-3 } \\
\text { (Second } \\
\text { Engine) }\end{array}$ & 10.7 & 10.9 & 0.2 & 1.869 & \\
\hline 3 & $\begin{array}{l}\text { A8-3 } \\
\text { (Third } \\
\text { Engine) }\end{array}$ & 10.7 & 10.6 & 0.1 & 0.935 & \\
\hline 4 & $\begin{array}{l}\text { B4-4 (First } \\
\text { Engine) }\end{array}$ & 13.2 & 13.4 & 0.2 & 1.515 & \multirow{3}{*}{13.333} \\
\hline 5 & $\begin{array}{l}\text { B4-4 } \\
\text { (Second } \\
\text { Engine) }\end{array}$ & 13.2 & 13.1 & 0.1 & 0.758 & \\
\hline 6 & $\begin{array}{l}\text { B4-4 } \\
\text { (Third } \\
\text { Engine) }\end{array}$ & 13.2 & 13.5 & 0.3 & 2.273 & \\
\hline 7 & $\begin{array}{l}\text { C6-3 (First } \\
\text { Engine) }\end{array}$ & 15.3 & 15.6 & 0.3 & 1.961 & \multirow{3}{*}{15.400} \\
\hline 8 & $\begin{array}{l}\text { C6-3 } \\
\text { (Second } \\
\text { Engine) }\end{array}$ & 15.3 & 15.2 & 0.1 & 0.654 & \\
\hline 9 & $\begin{array}{l}\text { C6-3 } \\
\text { (Third } \\
\text { Engine) }\end{array}$ & 15.3 & 15.4 & 0.1 & 0.654 & \\
\hline 10 & $\begin{array}{l}\text { D12-5 } \\
\text { (First } \\
\text { Engine) }\end{array}$ & 32.9 & 33 & 0.1 & 0.304 & \multirow{3}{*}{32.933} \\
\hline 11 & $\begin{array}{l}\text { D12-5 } \\
\text { (Second } \\
\text { Engine) }\end{array}$ & 32.9 & 32.6 & 0.3 & 0.912 & \\
\hline 12 & $\begin{array}{l}\text { D12-5 } \\
\text { (Third } \\
\text { Engine) }\end{array}$ & 32.9 & 33.2 & 0.3 & 0.912 & \\
\hline
\end{tabular}

$13.1 \mathrm{~N}$ while the third engine indicated a maximum thrust of $13.5 \mathrm{~N}$. For the first engine, the thrust had tapered to a constant

\section{DISCUSSION}

Figure 2 shows the the thrusts of 3 rocket engines of type A8-3. For the first engine, the maximum thrust was $11.1 \mathrm{~N}$. For the second engine, the maximum thrust achieved was $10.9 \mathrm{~N}$. The third engine gave a maximum thrust of $10.6 \mathrm{~N}$. In less than 0.5 seconds, the thrusts of all 3 engines tapered to it's constant value. Table 1 shows the maximum thrust denoted by the manufacturer which is $10.7 \mathrm{~N}$. For the first engine, there is a variation of $0.4 \mathrm{~N}$ between the measured thrust and the thrust given by the manufacturer. This variation translated to $3.738 \%$. This seems like an acceptable variation. For the second engine, the variation is $0.2 \mathrm{~N}$ which is $1.869 \%$ and this is also acceptable. And for the third engine, the variation is $0.1 \mathrm{~N}$ which is $0.935 \%$ and this is an acceptable variation.

In Figure 3, we can observe the thrusts of 3 rocket engines of type B4-4. Testing of the first engine gave us a maximum thrust of $13.4 \mathrm{~N}$. The second engine gave a maximum thrust of value of $3.9 \mathrm{~N}$ while for the second engine the thrust had tapered to a constant value of $3.8 \mathrm{~N}$. It can be seen that the third engine had a thrust which tapered to $4.1 \mathrm{~N}$. Table 1 indicated that the maximum thrust denoted by the manufacturer is $13.2 \mathrm{~N}$. For the first engine, the variation between the measured maximum thrust and the maximum thrust denoted by the manufacturer was $0.2 \mathrm{~N}$ which is $1.515 \%$. This somehow seems acceptable. For the second engine, the variation was $0.1 \mathrm{~N}$ which is $0.758 \%$ and this is deemed acceptable. For the third engine, the variation was $0.3 \mathrm{~N}$ which is $2.273 \%$. Even though this is above $1 \%$ the variation is still within an acceptable range.

In Figure 4, the maximum thrusts of 3 rocket engines of type C6-3 were shown. The first engine emitted a maximum thrust of $15.6 \mathrm{~N}$ while the second engine emitted a maximum thrust of $15.2 \mathrm{~N}$. The third engine showed a maximum thrust of $15.4 \mathrm{~N}$. The manufacturer had denoted that this type of engine is able to exert a maximum thrust of $15.3 \mathrm{~N}$. Peering Table 1 , for the 
first engine, the variation between the measured maximum thrust and the designated maximum thrust of the manufacturer was $0.3 \mathrm{~N}$. This value represents $1.961 \%$ of variation and is deemed acceptable. For the second engine, the variation is $0.654 \%$ which represents $0.1 \mathrm{~N}$ and it is an acceptable numerical figure. For the third engine, the variation is $0.1 \mathrm{~N}$ which is $0.654 \%$. This is still deemed acceptable.

In Figure 5, the maximum thrusts of engines of type D12-5 were recorded. The first engine showed a maximum thrust of $33 \mathrm{~N}$. The second engine produced a maximum thrust of $32.6 \mathrm{~N}$ and the third engine exerted a thrust of $33.2 \mathrm{~N}$. Looking at Table 1 , the manufacturer of this type of engine had stated that the maximum thrust produced by this engine is $32.9 \mathrm{~N}$. For the first engine, there was a variation of $0.1 \mathrm{~N}$ between the measured maximum thrust and the designated maximum thrust (as stated by the manufacturer). This variation is $0.304 \%$ and this is a good numerical figure. For the second engine, the variation was $0.912 \%$ which is $0.3 \mathrm{~N}$. And for the third engine, the variation was $0.3 \mathrm{~N}$ which is $0.912 \%$. The variations for the second and third engines are deemed acceptable.

Table 1 also shows the average maximum thrust (via measurement). For rocket engine A8-3, the average maximum thrust was $10.867 \mathrm{~N}$. For B4-4, the average maximum thrust was $13.333 \mathrm{~N}$. For C6-3, the average maximum thrust was $15.400 \mathrm{~N}$. And for D12-5, the average maximum thrust was $32.933 \mathrm{~N}$. The variances from the maximum thrust denoted by the manufacturer for engines A8-3, B4-4, C6-3, and D12-5 were $0.167 \mathrm{~N}, 0.133 \mathrm{~N}$, $0.1 \mathrm{~N}$, and $0.033 \mathrm{~N}$ respectively. All of the variances were below $1 \mathrm{~N}$ and thus all the variances were acceptable.

\section{CONCLUSIONS}

Four types of miniature rocket engines were tested and their thrusts were measured. An apparatus held the engines horizontally and a strain gauge measured their thrusts. The thrusts gained were compared with the thrusts denoted by the manufacturer of the rocket engines. Variations were calculated and the variations were within an acceptable range. The rocket engines were consistent in producing thrusts that were within the stipulated values set by the manufacturer and thus showed the engines were efficient in their burns.

\section{REFERENCES}

[1] Varnier, J., "Experimental Study and Simulation of Rocket Engine Freejet Noise", AIAA Journal, Volume 39, No. 10, October 2001, DOI : 10.2514/2.1199.

[2] Harridon, M., "Factors that Affect the Success of Search and Rescue Missions : Perceptions of Search and Rescue Crews of Malaysian Police Air Wing", International Journal of Scientific and Research Publications, Volume 10, Issue 11, November 2020, ISSN 2250-3153, DOI 10.29322/IJSRP.10.11.2020.p10727
[3] Bitter, M., "High Repetition Rate PIV Investigations on a Generic Rocket Model in Sub and Supersonic Flows", Exp Fluids (2011) 50 : 1019 - 1030 , Springer, DOI : 10.1007 / s00348-010-0988-8.

[4] Babuk, V.A., "Model of Aluminium Agglomerate Evolution in Combustion Products of Solid Rocket Propellant", Journal of Propulsion and Power, Volume 18, No. 4, July - August 2002, DOI : 10.2514/2.6005

[5] Desrochers, M.F., "A Ground Test Rocket Thrust Measurement System", Journal of Pyrotechnics, Issue 14, Winter 2001, pg 50-55.

[6] Penn, K., "Measuring Model Rocket Engine Thrust Curves", The Physics Teacher, Volume 48, Issue 9, December 2010, pg 591 - 593, DOI : $10.1119 / 1.3517023$

[7] Pappu, S., "Applications of Satellite Remote Sensing for Research and Heritage Management in Indian Prehistory", Journal of Archaeological Science, Volume 37, Issue 9, September 2010, Pages 2316 - 2331, DOI : 10.1016/j.jas.2010.04.005

[8] Harridon, M., "Incident Analyses of Helicopter Guimbal Cabri G2", International Journal of Scientific and Research Publications, Volume 10, Issue 12, December 2020, ISSN 2250-3153, DOI 10.29322/IJSRP.10.12.2020.p10809

[9] Harridon, M., "Perception of Search and Rescue Crew of Malaysian Police Air Wing towards General Issues of Search and Rescue", International Journal of Scientific and Research Publications, Volume 10, Issue 10, October 2020, ISSN 2250-3153, DOI : 10.29322/IJSRP.10.10.2020.p10630

[10] Campbell, T.A., "Model Rocket Project for Aerospace Engineering Course : Trajectory Simulation and Propellant Analysis", Department of Mechanical Engineering, The Catholic University of America, Washington D.C.

[11] Harridon, M., "Health Assessment of Academicians through Body Mass Index Evaluation and Relationship with Strain", International Journal of Scientific and Research Publications, Volume 10, Issue 11, November 2020, ISSN 2250-3153, DOI : 10.29322/IJSRP.10.11.2020.p10781

[12] Navarrete-Martin, L., "Sounding Rockets : Analysis, Simulation, and Optimization of a Solid Propellant Motor using Hopsan", Transportation Research Procedia 29 (2018) 255 - 267, DOI : 10.1016/j.trpro.2018.02.023.

\section{AUTHORS}

First Author - Mohd Harridon, Space Tech Center Universiti Kuala Lumpur Malaysian Institute of Aviation Technology, mdharridon@unikl.edu.my

Second Author - Haslinawati Besar Sa'aid, Space Tech Center Universiti Kuala Lumpur Malaysian Institute of Aviation Technology

Third Author - Hazariah Mohd Noh, Space Tech Center Universiti Kuala Lumpur Malaysian Institute of Aviation Technology

Fourth Author - Puteri Nur Syaza Wardiah, Space Tech Center Universiti Kuala Lumpur Malaysian Institute of Aviation Technology

Fifth Author - Muhamad Nurazmi Abas, Space Technology Division Serba Dinamik

Sixth Author - Mohd Abdul Karim, Space Technology Division Serba Dinamik

Seventh Author - Muhammad Zikry Hilmi, Space Technology Division Serba Dinamik

Eight Author - Mohammad Azlan Amran , Space Technology Division Serba Dinamik 